\title{
Dinâmica hidrológica do médio vale do rio Amola Faca, sul de Santa Catarina, Brasil: processos de erosão e deposição no canal
}

\author{
Hydrological dynamics in the middle portion of the Amola \\ Faca River Valley, Southern Santa Catarina, Brazil: processes of \\ erosion and channel deposition
}

Edna Lindaura Luiz

Universidade do Extremo Sul Catarinense - UNESC

\begin{abstract}
Resumo: O rio Amola Faca, situado no sul do estado de Santa Catarina, desce as escarpas da serra geral e apresenta fluxos de alta energia em função da grande amplitude altimétrica do relevo e da ocorrência de chuvas orográficas. No sopé da serra geral, encontra-se uma extensa planície, onde rio Amola Faca apresenta canal entrelaçado. Diversos pontos com erosão de margens e depósitos na forma de barras de canal e de meandro são observados. Os processos de erosão e deposição podem estar relacionados a mudanças naturais de longo ou curto tempo, porém também podem sofrer influência das ações humanas no uso da terra da bacia, de mudanças na rede de drenagem ou ainda na retirada de seixos dos depósitos do leito para a construção civil.
\end{abstract}

Palavras-chave: Rio Amola Faca. Dinâmica fluvial. Erosão fluvial. Deposição fluvial.

\begin{abstract}
The Amola Faca River, located in the southern portion of the Brazilian State of Santa Catarina, goes down the escarpment of the Serra Geral. It thus presents high relief energy due both to the broad range of altitudes in its topography and the common occurrence of orographic precipitation. At the pediment of the Serra Geral, the Amola Faca river opens into a broad plain where the river channel is braided. Several locations of erosion can be observed at its margins and deposits in the form of bars can be seen in the channel, while also meanders appear. Erosion and deposition can be related to natural changes in a short or long run, but they also can be the result of human actions caused by land use patterns in the river basin, changes in its drainage network, or the extraction of gravel deposits from the river ground for construction purposes.
\end{abstract}

Keywords: Amola Faca River. River dynamics. Fluvial erosion. Fluvial deposition. 


\section{INTRODUÇÃO}

Os rios que descem a escarpa do planalto, ou seja, a Serra Geral, no sul de Santa Catarina, podem apresentar fluxos de alta energia em função da grande amplitude altimétrica da escarpa e da ocorrência de chuvas orográficas. A fisiografia das bacias hidrográficas destes rios é bem diferenciada, pois há um desnível de até quase mil metros nos altos vales do rio principal e seus afluentes e uma extensa planície costeira onde estão localizados os médios e baixos vales.

É interessante compreender o quanto a dinâmica fluvial está adaptada a essas características e não apresenta mudanças significativas, como processos de erosão e deposição acentuados. Em outras palavras, o quanto a rede de drenagem consegue absorver os impactos de precipitações mais intensas que aumentam a vazão nos rios e as mudanças provadas pela ação humana na rede de drenagem e nos terrenos da bacia.

O episódio de precipitações excepcionais de dezembro de 1995 causou mudanças significativas nos vales dos afluentes do rio Amola Faca, os rios Pinheirinho e Figueira, nos municípios de Timbé do Sul e Jacinto Machado, sul de Santa Catarina. Nestes vales ocorreram deslizamentos, corridas de terra, enxurradas em terrenos da escarpa e inundações e fluxos torrenciais na planície em função de precipitações excepcionais concentradas em poucas horas (PELLERIN et al. 1996, 1997, 2002). Os cursos dos rios foram modificados por depósitos ou por erosão, o solo nas encostas foi erodido e transportado deixando a rocha pouco alterada exposta, a vegetação foi devastada, entre outros. Os habitantes do local disseram que nem eles e nem seus antepassados haviam presenciado um episódio semelhante a este antes. Contudo, a ocupação efetiva do lugar ocorreu somente há cerca de 130 anos atrás, sendo que anteriormente a região era ocupada por índios que não deixaram registros históricos acerca deste ambiente. Entretanto, vários depósitos de leques aluviais na planície ao pé da serra com diferentes graus de alteração, alguns inclusive já muito alterados e formando solos bem desenvolvidos, documentam este tipo de evento como recorrente ao longo da história evolutiva desta paisagem (PONTELLI, 1998; PONTELLI, 2005).

Os canais fluviais não são formas estáticas ao longo do tempo, processos de erosão, transporte e deposição podem alterar sua forma e posição por causa de mudanças ambientais na bacia. Estas mudanças são resultados do trabalho do rio, ou seja, dos processos de erosão, transporte e deposição fluvial (CHRISTOFOLETTI, 1981, SUGUIO, BIGARELLA, 1990). O trabalho do rio depende da turbulência e da vazão do fluxo e ainda da carga de sedimentos que ele transporta.

A erosão dos rios pode ser efetuada pelos processos de corrasão, corrosão e cavitação ao longo do seu leito. Contudo, a maior parte dos sedimentos que são transportados e depositados pelos rios é, na verdade, erodida das encostas da bacia hidrográfica por outros agentes erosivos, como a chuva e os deslizamentos.

Os sedimentos podem ser transportados pelo rio de três formas: como carga dissolvida (íons de cálcio, potássio, cloretos, etc.); como carga em suspensão (silte e argilas), resultante da turbulência do fluxo; como carga de fundo ou de leito (areias, grânulos, calhaus, entre outros fragmentos maiores), nesta modalidade, as partículas são transportadas por arraste, saltação, rolamento (CHRISTOFOLETTI, 1981).

Em relação à carga de fundo, dois conceitos são importantes de destacar: a capacidade do rio, a qual determina a maior quantidade de sedimentos que um rio pode deslocar como sua carga de fundo e, competência do rio, que corresponde ao maior diâmetro encontrado entre os 
sedimentos transportados como carga de fundo.

A deposição da carga detrítica carregada pelos rios pode ocorrer quando há diminuição da competência ou da capacidade fluvial. Essa diminuição pode ser causada pela redução da declividade do leito do rio, pela redução do volume do fluxo ou pelo aumento do calibre da carga detrítica. Formas típicas originadas pela deposição dos rios são as planícies aluviais.

As variáveis que comandam o trabalho do rio são: a vazão e a carga de sedimentos. A variação da vazão de um rio muda a velocidade do fluxo, a seção transversal (largura e profundidade do canal), a rugosidade do leito e, ainda o balanço de sedimentos (carga de sedimentos), pois ela determina a competência e a capacidade fluvial (RICE, 1983).

Rios equilibrados têm tendência a não erodirem e nem depositarem, simplesmente transportam os sedimentos que recebem das encostas (CHRISTOFOLETTI, 1980).

Desta forma, a presença de processos de erosão e de deposição no canal representa ajustes a mudanças na dinâmica do rio. Essas mudanças podem ser naturais ou antrópicas. Mudanças naturais na dinâmica de um rio incluem alterações climáticas, variação do nível de base, como variações do nível do mar (nível de base geral das bacias hidrográficas) ou tectonismo (RICE, 1983; SUGUIO e BIGARELLA, 1990). Além de mudanças de longo termo, também episódios pouco freqüentes e de alta magnitude, como chuvas muito intensas, podem provocar alterações na vazão e, conseqüentemente, no trabalho do rio. Suguio e Bigarella, (1990) comentam sobre a ligação entre a existência de terraços nas planícies e o rebaixamento do nível de base dos rios.

Pode-se classificar as modificações impostas pelo homem na bacia hidrográfica em dois grupos (CUNHA, 1994):

- modificações diretas no canal de drenagem: para modificar a vazão (armazena- mento das águas ou seu desvio) ou para alterar a forma do canal (retilinizações, canalizações), para extração de areia e cascalho, para estabilização de margens. Essas obras alteram a seção transversal, o perfil longitudinal do rio, o padrão de canal, enfim, os processos de erosão, transporte e deposição realizados pelo do rio.

- modificações indiretas: através do uso do solo na bacia: tais como o desmatamento, a drenagem das planícies (rebaixamento do lençol freático), urbanização (impermeabilização), entre outras. Estas interferências modificam o comportamento da vazão e da carga sólida do rio. Há ainda o emprego de agrotóxicos nas lavouras e a deposição de efluentes urbanos e industriais nos rios que modificam a qualidade de suas águas.

Alguns autores conseguiram verificar mudanças no canal e na dinâmica hidrológica do rio, como Cunha (1995) na bacia do rio São João, Rio de Janeiro, em virtude da implantação de uma barragem. Brookes (1985) analisa as modificações apresentadas por rios canalizados na América do Norte e na Europa e sugere algumas opções para a não canalização. Wyzga (1993) mostra a resposta do rio Raba, nos Cárpatos da Polônia, a processos de regularização do canal fluvial.

Christofoletti (1980) comenta sobre o perfil de equilíbrio do rio e coloca que "há solidariedade intrínseca entre todos os pontos do perfil" (op cit., p. 97). Assim, modificações em um ponto do canal se transmitem para outros pontos procurando um ajuste para todo o perfil longitudinal do rio. O mais difícil é estimar o tempo de resposta do sistema fluvial e onde e como acontecerão as alterações para o encontro de um novo equilíbrio.

O presente artigo pretende discutir a dinâmica hidrológica atual do rio Amola Faca a partir de estudos efetuados em campo e em escritório, com especial ênfase na identificação de processos de erosão e sedimentação no canal. 


\section{LINDAURA LUIZ \\ CARACTERÍSTICAS GERAIS DA BACIA DO RIO AMOLA FACA}

A bacia do rio Amola Faca se localiza ao sul de Santa Catarina (Figura 1) e abrange dois compartimentos de relevo diferenciados: As encostas íngremes e extensas da Serra Geral e as terras baixas e pouco movimentadas da planície costeira. As encostas da serra Geral estão recobertas quase totalmente por vegetação de porte arbóreo da formação floresta ombrófila densa montana e submontana (Figura 2). No sopé da serra e nos fundos de vales aí localizados, são encontradas plantações de culturas anuais no sistema de agricultura familiar. Nas terras da planície costeira, a agricultura comercial, representada pela rizicultura, é dominante e muda completamente a paisagem, tanto do ponto de vista do desaparecimento da vegetação nativa da floresta ombrófila densa aluvial como da mudança do relevo por causa da retificação de canais, drenagem de terrenos encharcados e cortes de pequenas colinas no meio da planície ("lombas" no dizer local) para construção das canchas de arroz.

Dantas et al. (2005) colocam que a bacia do rio Amola Faca tem vales encaixados nas encostas da Serra Geral com nítido controle estrutural, canal entrelaçado e anastomosado no médio curso e meandrante no baixo curso. Todavia, junto a sua confluência com o rio da Pedra apresenta novamente um padrão anastomosado. Os autores acima citados explicam que as diferenças no padrão de canal do rio Amola Faca estão relacionadas com a grande quantidade e o tamanho dos sedimentos que chegam ao rio provenientes das terras altas da bacia. Contudo, a observação do mapa elaborado por Pontelli (2005) permite discutir que o meandramento do canal do rio Amola Faca ocorre também no médio curso e que este possa estar relacionado com o encaixe da drenagem em terrenos com litologias mais resistentes e em sistemas de lineamentos (meandros estruturais), como parece ser o caso do meandro que o rio desenvolve entre as localidades de Vila Progresso e Sanga d'Areia.

A planície possui depósitos de leques aluviais de variadas idades que constroem colinas alongadas entremeadas por canais de fundo chato. Tais depósitos são oriundos de processos de alta energia que são recorrentes no tempo geológico da área (PONTELLI, 1998) (Figura 3).

Os solos nas encostas da Serra Geral tendem a ser rasos, o que associado aos grandes desníveis, não permite significativo armazenamento de água, mas provoca o aumento rápido da vazão nos momentos das precipitações.

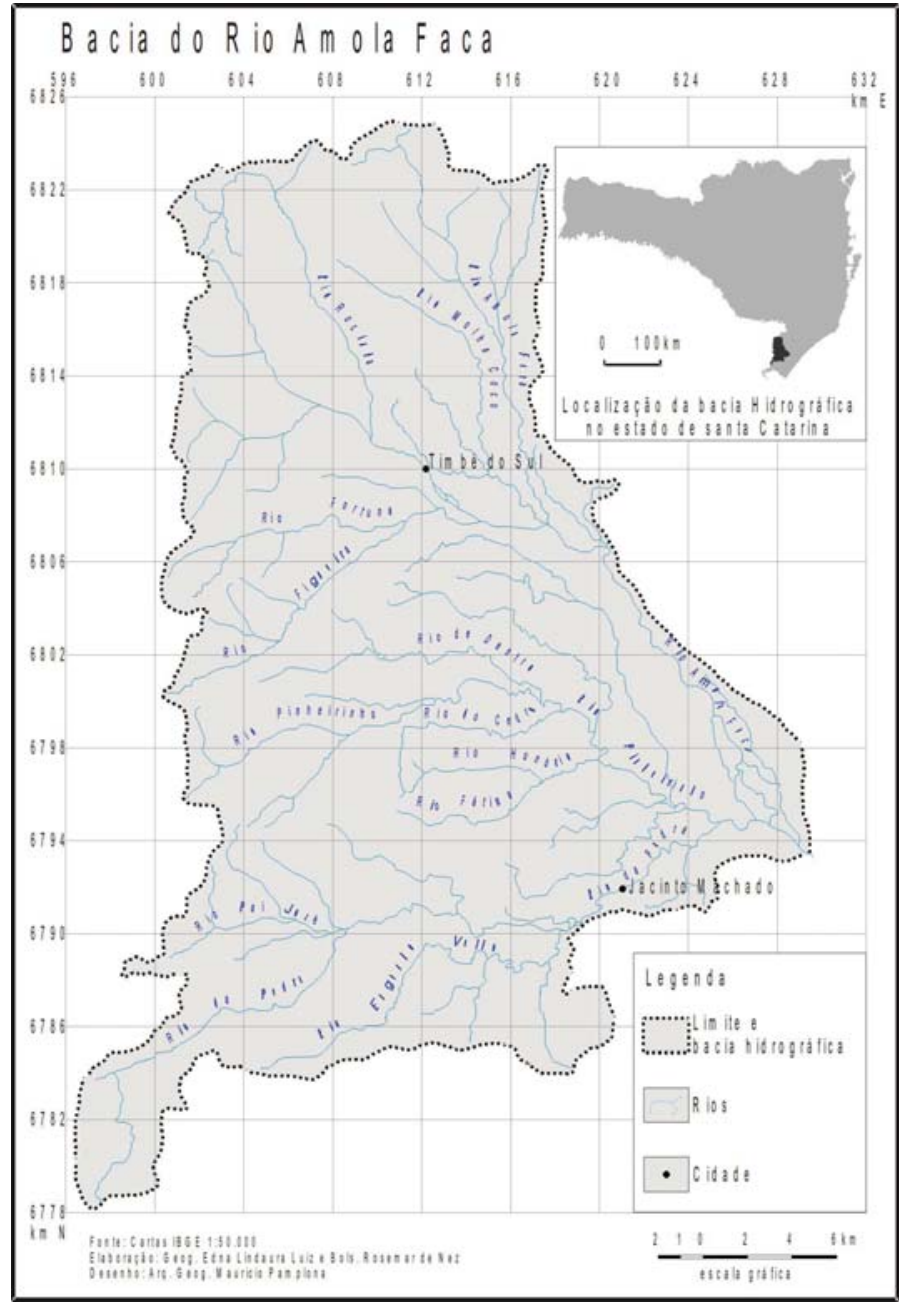

Figura 1 - Localização da bacia do rio Amola Faca. 


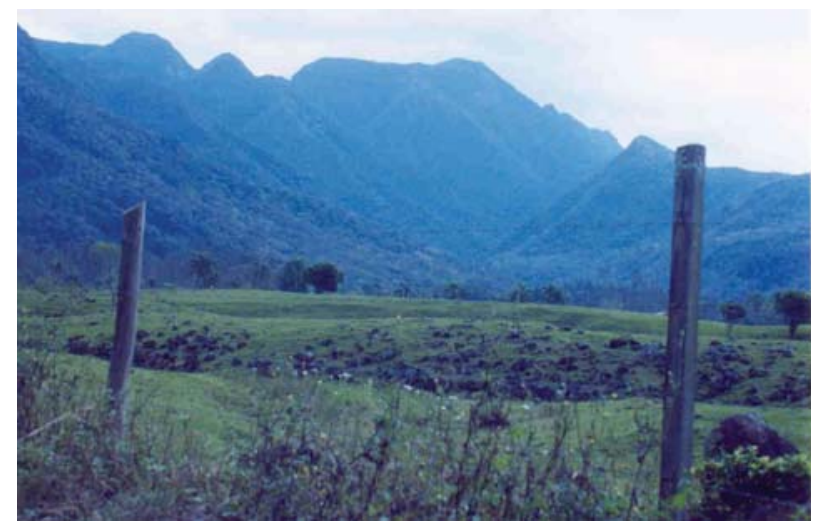

Figura 2 - Planície do rio Amola Faca em primeiro plano e encostas da Serra Geral ao fundo.

Foto: Gilberto Tonetto, set. 2006.

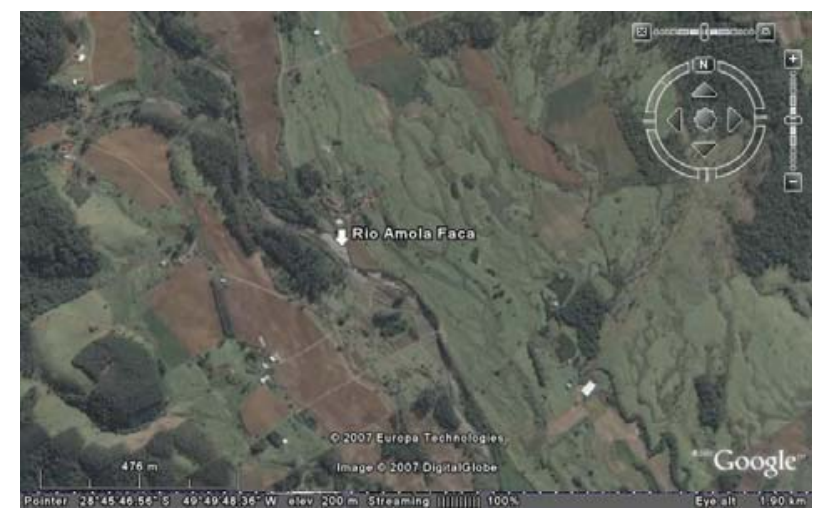

Figura 3 - Planície do rio Amola Faca no seu médio vale, observar o entrelaçamento do canal atual (onde está a seta com o nome do rio) e, na planície, os vários segmentos de leitos e depósitos na forma de leques aluviais.

Fonte: Imagem Programa Google Earth, 2007.

\section{MATERIAIS E MÉTODOS}

Para compreender a dinâmica atual do rio Amola Faca em seu médio vale foram efetuadas saídas a campo para identificação de pontos com erosão no canal, para localização de sítios de extração de seixos, para levantamento de seções transversais e medidas de fluxo. Em escritório foram sistematizados dados e realizados cálculos de morfometria da bacia. Também foram elaborados mapa base e perfil longitudinal do rio Amola Faca.

A partir das cartas topográficas do IBGE que englobam a bacia do rio Amola Faca (folhas Turvo, Jacinto Machado, São Bento Baixo, Silveira) foi confeccionada um mapa base na escala 1:50.000 contendo a rede de drenagem, as principais localidades e cidades, as principais rodovias. A carta base serviu para a localização no campo e para auxiliar nos cálculos de morfometria da bacia e loclaizaçã oda seções transversais e outros dados.

O perfil longitudinal foi confeccionado a partir das cartas topográficas do IBGE na escala 1:50.000. O método consiste em se marcar as intersecções entre as curvas de nível e o traçado do rio principal (Amola Faca), anotando-se a distância entre essas intersecções e o valor das altitudes das curvas de nível por onde o rio cruza, traçandose em seguida o perfil longitudinal.

As medidas para a análise morfométrica foram efetuadas considerando a bacia do rio Amola Faca até sua confluência com o rio da Pedra, onde a partir deste ponto o sistema hidrográfico passa a ser denominado de rio Itoupava. Foram utilizados os instrumentos curvímetros e planímetros.

A morfometria da bacia fluvial dá informações sobre a adaptação da rede hidrográfica com o substrato geológico e com o clima. A caracterização morfométrica serve ainda para comparar duas bacias hidrográficas e indicar a propensão de uma determinada bacia em sofrer com os eventos de cheias e o tamanho da área drenada necessária para manter um metro canal de escoamento, entre outras informações. Foram obtidos os seguintes dados:

a) ordem dos canais

b) comprimento dos segmentos dos rios das diferentes ordens encontradas

c) Parâmetros da bacia: Faca)

- área da bacia do rio Itoupava (Amola

- perímetro da bacia do rio Itoupava (Amola Faca)

d) índice de comprimento dos rios de diferentes ordens 
e) índice de bifurcação

f) relação do índice de bifurcação e do comprimento médio dos canais

g) densidade de rios

h) densidade de drenagem

i) forma da bacia.

A identificação dos processos de erosão e deposição no médio vale do rio Amola Faca foi realizada através de observações em campo, de fotografias e de entrevista com moradores ribeirinhos.

A medição das seções transversais foi executada através de levantamento topográfico com uso de nível, trena e balizas.

A velocidade pôde ser determinada com o auxílio de objetos flutuantes (uma laranja, por exemplo). Este objeto era colocado no rio e media-se o tempo que ele levava para percorrer determinada distância pré - definida.

O mapeamento da bacia e a locação dos pontos com erosão e deposição foram efetuados a partir de uma carta base em meio digital fornecida pelos laboratórios de Análise Ambiental e de Geoprocessamento do Depto. de Geografia da Universidade Federal de Santa Catarina.

\section{RESULTADOS}

O perfil longitudinal do rio Amola Faca mostra um rio com grandes desníveis e altitudes no seu alto vale e parte do baixo vale, variando de altitudes acima de $1.200 \mathrm{~m}$ até cerca de $10 \mathrm{~m}$. Em cerca de $10 \mathrm{~km}$ de percurso, o rio passa de uma altitude de $1.200 \mathrm{~m}$ para 200m, um desnível de $1000 \mathrm{~m}$.
A partir da análise da rede hidrográfica do rio Amola Faca sobre mapas na escala 1:50.000, foi possível verificar que a bacia possui 315 canais de 1 a. ordem, 74 de $2 a$. ordem, 20 de 3 a. ordem, 5 de 4 a. ordem, 2 de $5 a$. ordem e 1 de $6 a$. ordem, com uma extensão total de canais de $814,51 \mathrm{~km}$ de canais. A área da bacia é de 1128.63 $\mathrm{km}^{2}$ e seu perímetro é de $185.65 \mathrm{~km}$. A relação de bifurcação entre os canais de 3a para e de 4a para 5a ordens são inferiores a 2, diferente do que preconizava Horton (1945), mas isto é explicado pela configuração da rede hidrográfica desta bacia que apresenta padrão entrelaçado e anastomosado em seu médio e baixo vale, produzindo anomalias nas medidas dos canais de ordens superiores localizadas nestas áreas. $\mathrm{O}$ mesmo ocorre com a relação entre os comprimentos médios dos canais de ordens sucessivas, pois Strahler (1982) comenta que a tendência esperada é a de que o comprimento dos segmentos de rios se triplique aproximadamente cada vez que se aumente a ordem dos rios. Contudo, isto não é o encontrado para os rios de $4^{a}, 5$ a e 6a ordens na bacia do rio

Perfil Longitudinal do Rio Amola Faca

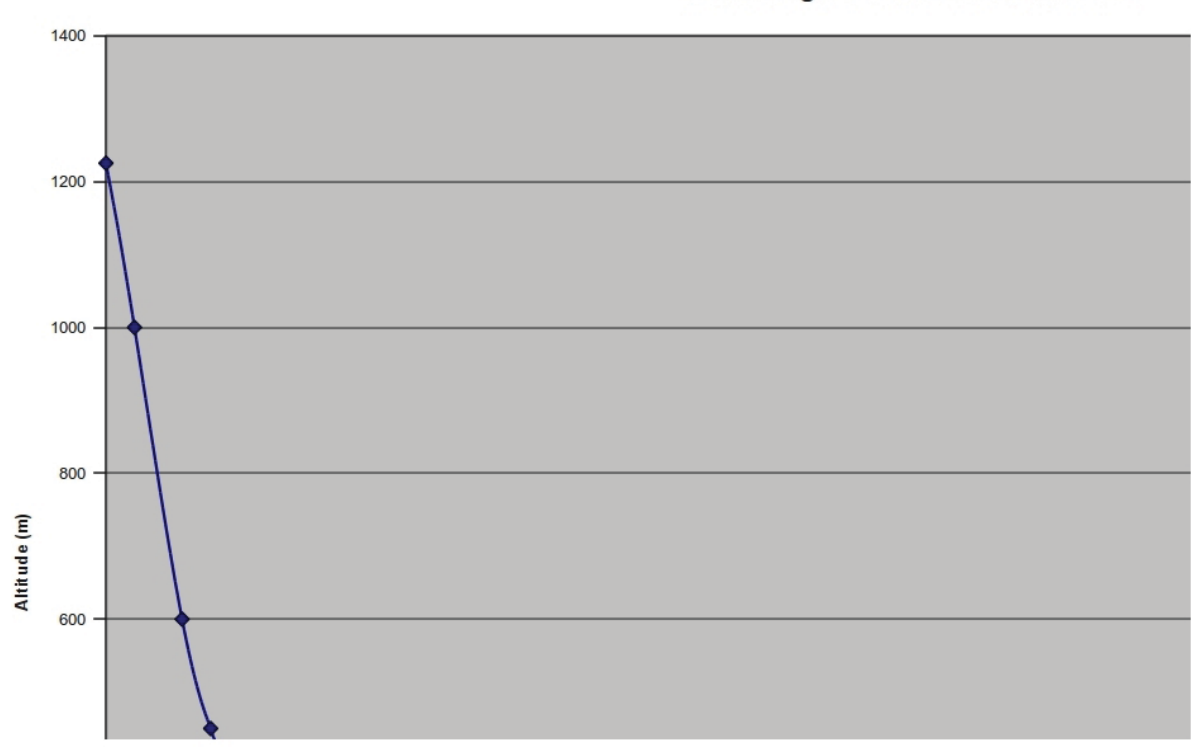

Figura 4 - Perfil longitudinal do rio Amola Faca. Observar o grande desnível e a grande diferença de altitude que conferem a esta bacia características específicas, como fluxos de alta energia e grande carga sedimentar pela ocorrência de chuvas orográ ficas excepcionais. 
Amola Faca. Horton (1945) estabeleceu que a relação entre o índice do comprimento médio dos canais e o índice de bifurcação é um importante fator entre a composição da drenagem e o desenvolvimento fisiográfico das bacias hidrográficas. Isso porque, se a relação entre o comprimento médio e o índice de bifurcação for igual, o tamanho médio dos canais crescerá ou diminuirá na mesma proporção. Caso não seja igual, o que é mais comum, o tamanho dos canais poderá diminuir ou aumentar progressivamente com a elevação da ordem dos canais, pois o que irá influenciar não serão as leis de desenvolvimento da drenagem, mas os fatores morfológicos e geológicos que ainda controlam o estabelecimento da rede de drenagem. Sendo este o caso da bacia o rio Amola Faca, a geologia e a morfologia controlam a configuração da rede de drenagem, além dos processos erosivos e de sedimentação. A densidade de rios da bacia é de 0,36 rios $/ \mathrm{km}^{2}$ e a densidade de drenagem é de $0,72 \mathrm{~km} / \mathrm{km}^{2}$. O índice de forma da bacia mostra que esta não é uma bacia circular e por isso não seria propensa a inundações, contudo a sua fisiografia e a ocorrência de chuvas orográficas excepcionais na área originam grandes deslizamentos, corridas de terras, com chegada de muita água e sedimentos nos trechos de canais da bacia do sopé da Serra Geral, provocando grandes enxurradas, fluxos torrenciais e inundações. O coeficiente de manutenção indica que são necessários 1,388 m2 de área para manter $1 \mathrm{~m}$ de canal de escoamento na bacia.

O canal do rio Amola Faca possui diferenciações significativas ao longo de sua extensão nos diferentes compartimentos de relevo expostos anteriormente. Nas encostas da Serra Geral (rio Rocinha), o canal é encaixado e com alto gradiente (Figura 4 - perfil longitudinal do rio). Em campo, foi possível verificar na transição entre o sopé da serra geral e a planície, que o canal apresenta muitos depósitos de clastos (fragmentos maiores que o tamanho areia) no seu leito e evidências de migrações laterais a partir da observação de braços de leitos abandonados reconhecidos por meio de depósitos de forma alongada de clastos com embricamento (evidência de fluxos). Tais depósitos se encontram rebaixados em relação à planicie em volta. Em um dos pontos observados ao longo do canal neste setor (Figura 5), a margem esquerda apresenta um desnível significativo em relação ao nível geral da planície, com processos de erosão por solapamento provocado pelo fluxo em momentos de maior vazão, inclusive com quedas de árvores. Mais a jusante do ponto descrito acima, no local onde foi executada a seção transversal 04, também existem segmentos de leitos abandonados com presença de muitos clastos.

No leito atual do rio, quando a vazão é pequena em virtude de períodos de poucas chuvas, a água corre por baixo dos depósitos de fundo e poucas vezes aflora na superfície (Figura 05). Os clastos apresentam diferentes tamanhos, desde fragmentos com um metro de diâmetro até pequenos cascalhos com poucos centímetros. A grande maioria dos clastos encontrados é de basalto, com poucas exceções de fragmentos formados por arenito Botucatu.

A planície é constituída de vários lóbulos (colinas baixas e alongadas) (Figuras

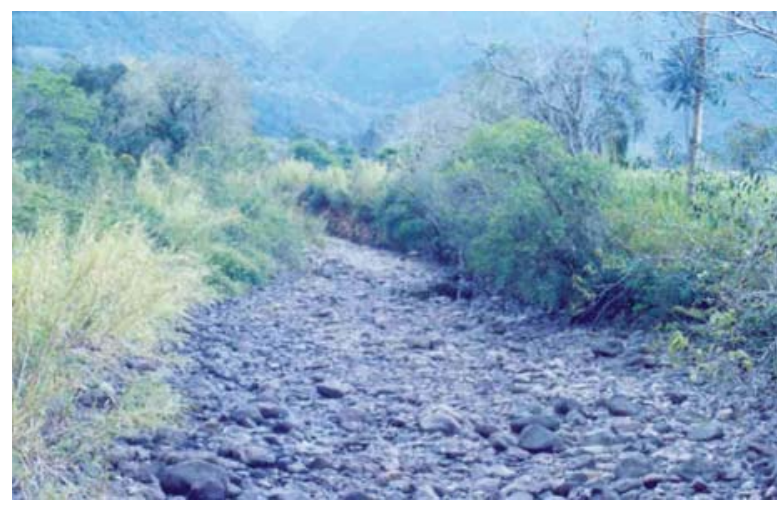

Figura 5 - Leito do rio Amola Faca no sopé das encostas da Serra Geral entulhado de sedimentos clásticos de diferentes tamanhos. Visão para montante. Notar a falta de fluxo na superfície, porém este ocorre abaixo dos clastos e aflora mais a jusante. A foto foi tirada próximo do local onde foi realizada a seção transversal 03. Observar a margem abrupta à direita e ao fun do da foto. Foto: Gilberto Tonetto, set. 2006. 
02), que nada mais são do que antigos depósitos de leques aluviais, demonstrando a grande dinâmica do leito do rio Amola Faca neste setor

Em conversa com uma Senhora, moradora do local, ela nos informou que o atual leito do rio Rocinha (Amola Faca) neste trecho foi escavado pelas chuvas torrenciais de dezembro de 1995. Por causa do aumento da vazão e da grande quantidade de sedimentos e detritos que transportava de montante, o rio migrou de seu leito original e escavou depósitos mais antigos da planície, uma vez que houve um represamento a montante, onde fragmentos de rochas, lama e árvores obstruíram o canal. A própria vegetação presente nas margens ajudou no represamento, pois a erosão provocada pela energia da vazão solapa as terras ribeirinhas e faz quedar as árvores.

O atual leito é mais profundo do que o antigo e apresenta desnível maior da sua margem esquerda em relação à direita (Figura 6). O desnível e a existência de material inconsolidado não coberto por vegetação nesta margem indicam a possibilidade de ocorrência de processos erosivos em momentos de vazão mais significativa, o que poderá comprometer a estrutura de uma ponte situada no local. A moradora entrevistada coloca que a escavação do leito que o rio ocupa hoje é fruto também de uma chuva muito intensa em 1996 que aumentou a vazão do rio e de outras posteriores.

Seguindo para jusante, o canal do rio Rocinha (Amola Faca) avança sobre as terras planas e baixas da planície costeira, $\mathrm{o}$

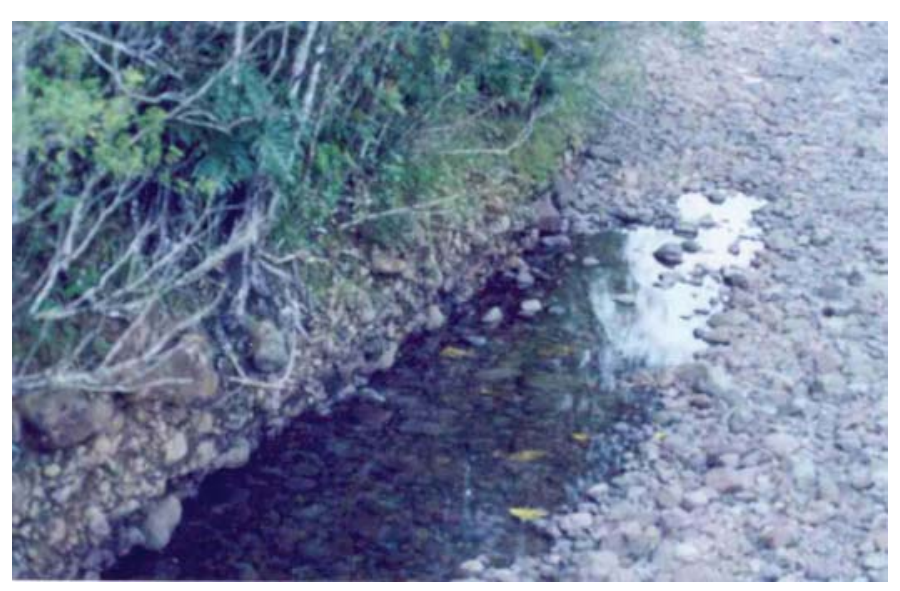

Figura 6 - Rio Amola Faca no local onde foi medida a seção transversal 04 . Observar a pequena quantidade de água no leito.

Foto: Gilberto Tonetto, set. 2006. que permite que o seu perfil longitudinal seja mais suave (menores gradientes). A ocorrência de segmentos de leitos abandonados é comum e sua distribuição na planície observada em imagem de satélite (Figura 3) demonstra uma configuração de leques aluviais, ou seja, extravasamento do fluxo dos canais e seu espalhamento em direção à planície. $O$ canal se torna entrelaçado e o fluxo se divide por dois ou mais canais, diminuindo a quantidade de água em cada leito. Além do entrelaçamento do canal, é possível observar também a sinuosidade dos canais em alguns pontos da planície, configurando meandros que avançam sobre as terras da planície (erosão) na sua margem côncava e apresentam depósitos de clastos na sua margem convexa.

Entre os pontos em que foram levantadas as 3a. e 4a seções transversais do rio existe um sítio de extração de clastos do canal que modifica a dinâmica fluvial local. A atividade de extração executa um transporte de todos os clastos para uma margem do rio e o seu acomodamento em montes para facilitar a retirada por caminhões, isso aumenta a profundidade do canal no lado oposto e a energia do fluxo por diminuição do atrito dele com o fundo do leito.

No local escolhido para a medição da 1a seção transversal do canal do rio Amola Faca existe uma ponte de concreto que praticamente restringe o fluxo de água, pois foi construída sobre o leito com canos de concreto (Figura 07). Na época da realização da medida da seção transversal 01 (agosto/2006), o fluxo d'água estava muito baixo, porém parece que esta situ- 


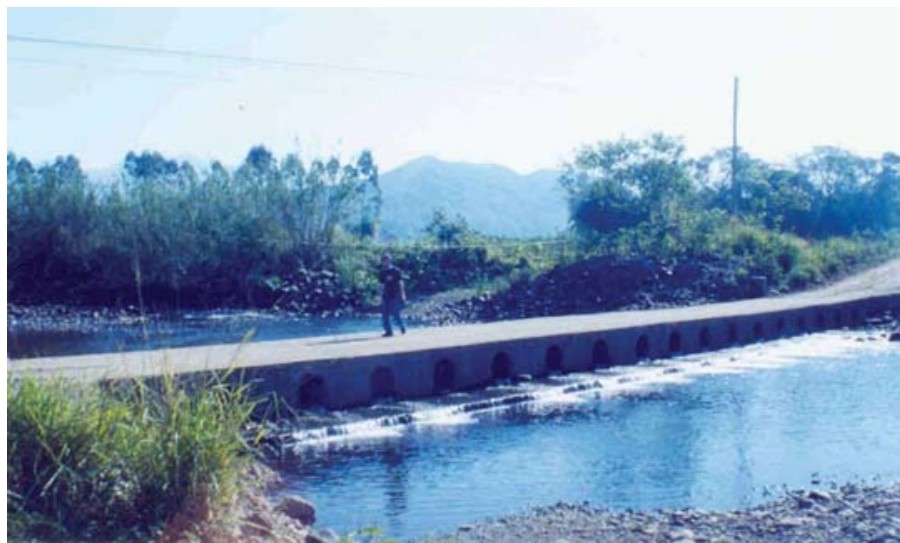

Figura 7 - Leito do rio Amola Faca no local onde foi medida a primeira seção transversal, visão para montante. Observar a restrição do fluxo por causa da construção da ponte de concreto que deixa passar a água somente através de canos de concreto. Nesta área também são extraídos clastos.

Foto: Edna Luiz, ago. 2006.

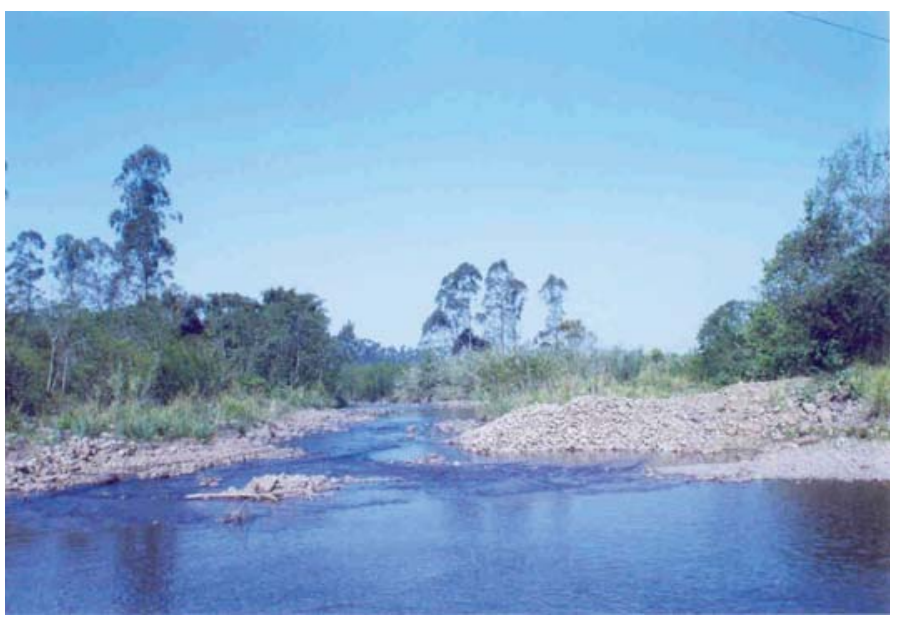

Da seção transversal 3 até a seção transversal 1 , as margens do rio são escavadas em depósitos antigos de clastos ainda sem intemperismo, mas já colonizados por vegetação pioneira de porte herbáceo e arbustivo.

Seguindo em direção à jusante, o entrelaçamento do canal é mais evidente e as áreas de cultivo de arroz se expandem na planície. Na ponte sobre o rio Amola Faca na rod. BR 285, o leito apresenta mais vazão do que nos trechos de montante, pois recebe mais afluentes até este ponto, e se apresenta mais encaixado, com margens com desnível de mais de três metros entre a linha d'água e o nível da planície (Figura 9 e 10).

Existem também depósitos de clastos junto às margens e também no centro do leito. Inclusive, este depósito já se encontrava colonizado por alguns indivíduos de uma espécie pioneira quando foi medida a seção transversal 02 , evidenciando a manutenção de pequenas vazões ao longo do tempo que não chegavam a submergir este banco de sedimentos. Contudo, uma curvatura do leito indica processo de meandramento neste trecho com erosão da margem

Figura 8 - Leito do rio Amola Faca no local onde foi medida a primeira seção transversal, visão para jusante. Observar o banco de sedimentos situado no centro do canal e aqueles situados junto das margens. Notar também o acúmulo de sedimentos clásticos feito pelo homem na margem para a posterior extração. Foto: Edna Luiz, ago. 2006.

ação vinha se mantendo assim há algum tempo, pois já existia vegetação pioneira colonizando os depósitos de barra de canal (Figura 9). Observações realizadas em fevereiro de 2007 mostraram que as chuvas mais abundantes de verão aumentaram a vazão do rio e o fluxo cobriu tais depósitos, destruindo a vegetação pioneira que aí havia se instalado.

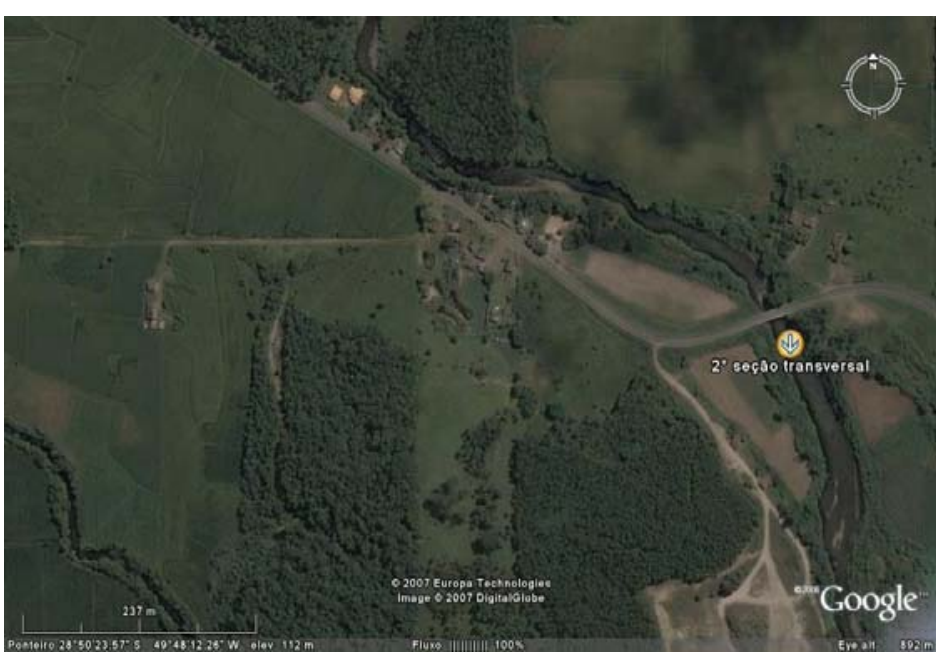

Figura 9 - Canal do rio Amola Faca cruzando a Rod. BR 285 entre os municípios de Turvo e Timbé do Sul. Observar a presença de mais água no canal e o padrão meandrante.

Fonte: Imagem Programa Google Earth, 2006. 


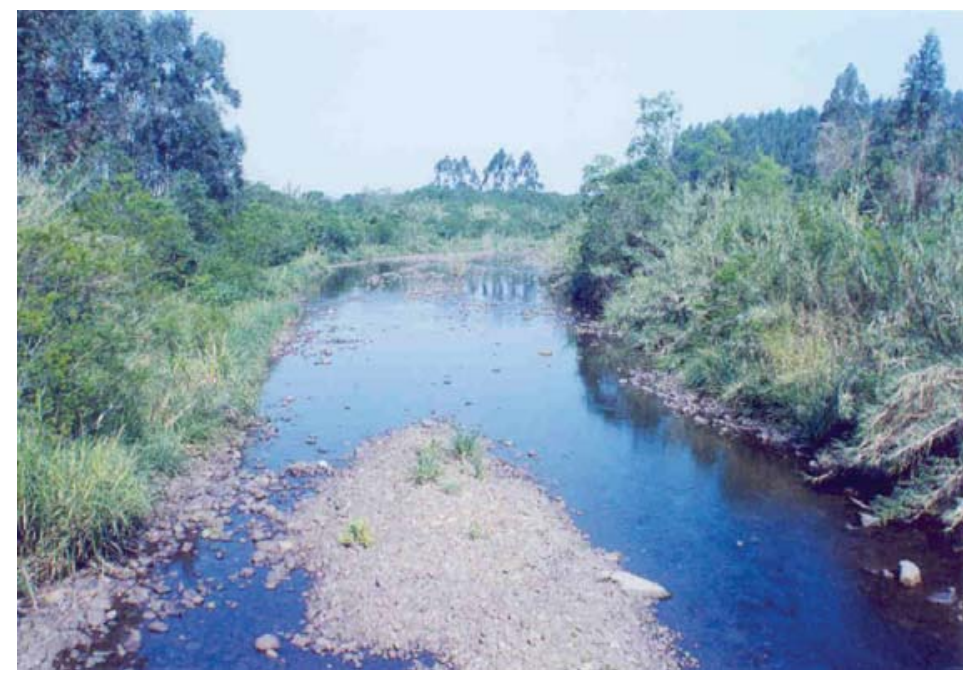

Figura 10 - Canal do rio Amola Faca no local onde foi realizada a medida da segunda seção transversal. Visão para jusante. Observar o banco de sedimentos no centro do leito já colonizado por vegetação pioneira, o que evidencia a estabilidade deste depósito ali e a sua não submersão. Foto: Edna Luiz, ago. 2006.

\section{(Figura 11).}

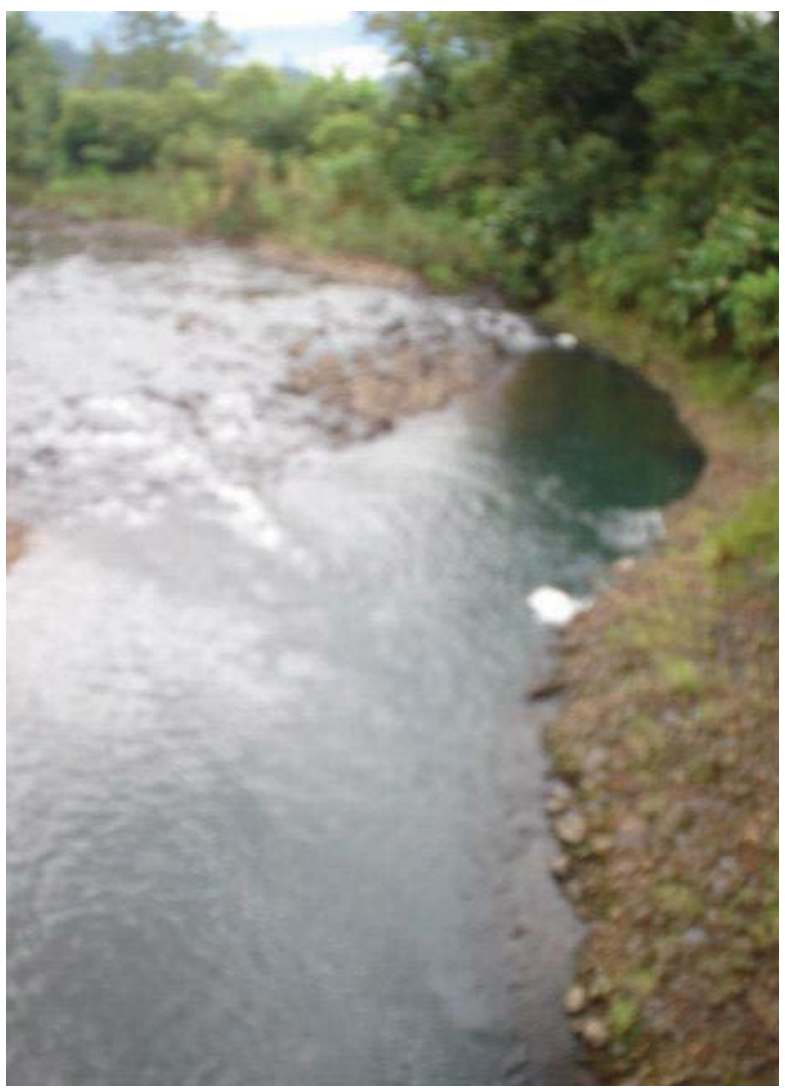

Figura 11 - Canal do rio Amola Faca no local onde foi realizada a medida da segunda seção transversal. Visão para montante. Observar o processo de meandramento do rio, com conseqüente erosão da margem côncava. Foto: Yasmine Cunha, abr. 2006.
Em plena planície, no trecho do canal do rio Amola Faca próximo ao Morro Dois Irmãos, existe uma praça de retirada de clastos de responsabilidade da Prefeitura Municipal de Turvo, segundo uma placa no local. As margens do canal neste trecho apresentam sinais de erosão e estão quase sem cobertura vegetal (Figura 12). Ocorre ainda no centro do leito uma ilha de sedimentos com colonização de vegetação pioneira. Os clastos apresentam embricamento na direção do fluxo d'água (Figura 13).

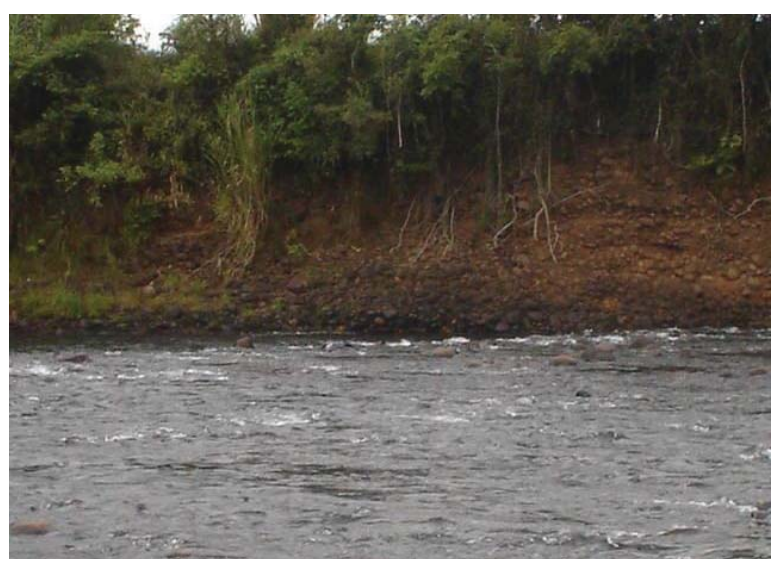

Figura 12 - Margem do rio Amola Faca modelada em depósitos de seixos antigos próximo ao Morro Dois Irmãos. A montante desta margem existe uma praça de extração de seixos. Foto: Yasmine Cunha, abr. 2006.

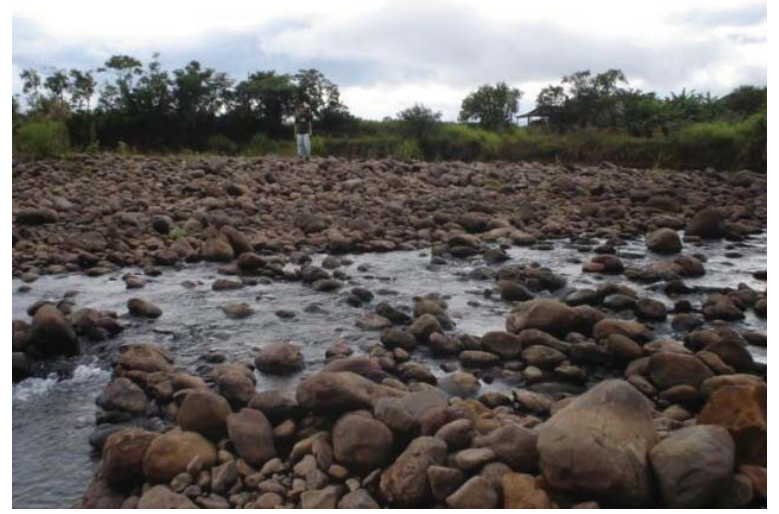

Figura 13 - Leito do rio Amola no médio vale próximo ao Morro Dois Irmãos. Visão para jusante. Observar a grande quantidade de clastos embricados no leito. Foto: Yasmine Cunha, abr./ 2006. 
A jusante do trecho descrito acima é encontrada em um nível de terraço bem marcado próximo ao canal, indicando aprofundamento do nível de base e conseqüente ajuste do rio. A margem esquerda do canal possui um desnível de aproximadamente cinco metros neste trecho do rio e apresenta um depósito de clastos na sua base. Também foi possível observar motores puxando água do rio para as lavouras de arroz (Figura 14). Na planície junto ao rio, existem troncos de eucaliptus tombados com raiz a mostra. Este fenômeno ocorreu durante o episódio de chuvas intensas e aumento da vazão de dezembro de 1995, segundo o depoimento de uma moradora do local. As raízes das árvores tombadas ainda apresentavam materiais do solo do local, o qual era uma massa de material fino constituído por silte, argila, areia e muitos cascalhos e grãos maiores, mostrando a constituição da planície. Existem evidências de erosão atual da margem neste trecho.

Seguindo através da planície costeira em direção à cidade de Turvo, próximo da localidade Rodeio d'Areia, é possível observar no leito do rio Amola Faca a presença de represas para acumular água para a rizicultura (Figura 15). Aqui o leito é muito raso, sem desnível em relação à planície lateral. Depósitos de clastos afloram no leito e nas margens.

Mais a jusante do ponto descrito acima, junto de uma ponte que corta o Rio Amola Faca, existem depósitos de seixos consolidados (conglomerados) nas margens do leito. Estes depósitos indicam relativa estabilidade e longo tempo de recobrimento para a sua consolidação. $\mathrm{O}$ avanço da erosão lateral do rio indica um período de instabilidade ambiental e retomada erosiva. Também próximo da entrada para localidade de Santana, a erosão nas margens do canal expõe depósito de clastos consolidados (Figura 16). A cobertura vegetal de porte arbóreo acaba sendo

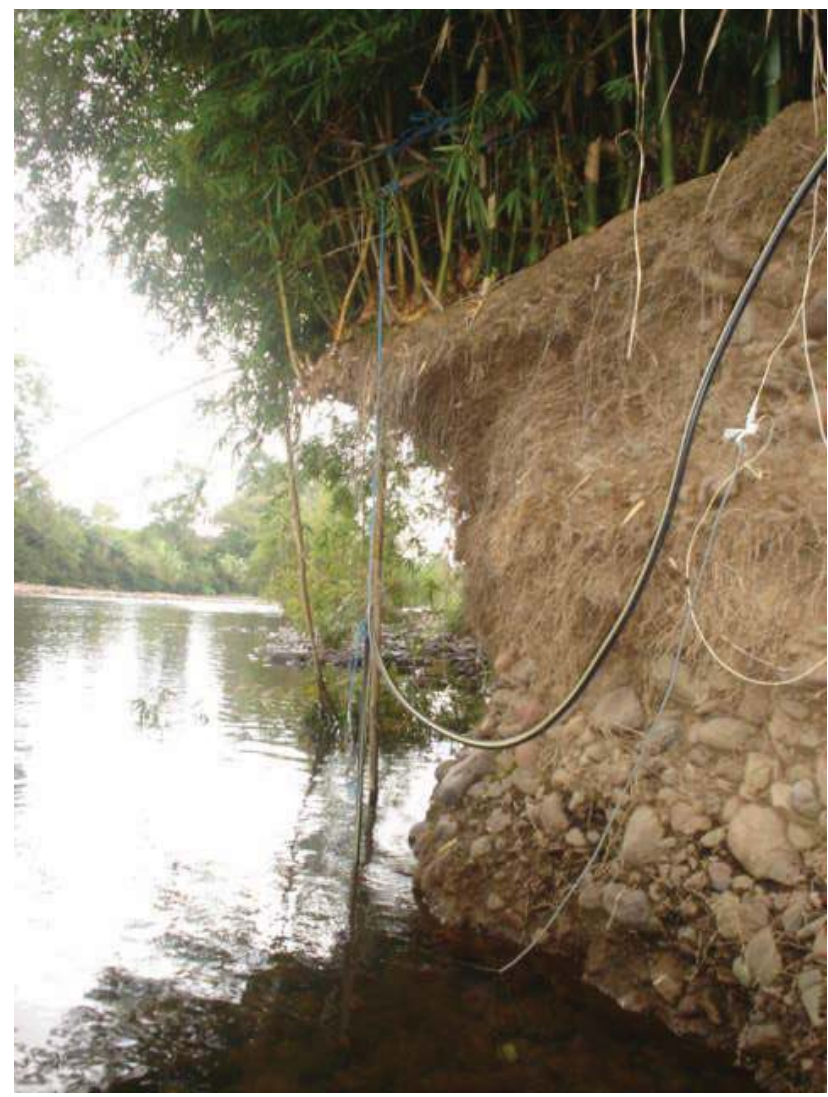

Figura 14 - Presença de bombas e mangueiras para extrair água para agricultura e outras atividades no leito do rio Amola Faca, próximo ao Morro Dois Irmãos. Foto: Yasmine Cunha, abr. 2006.

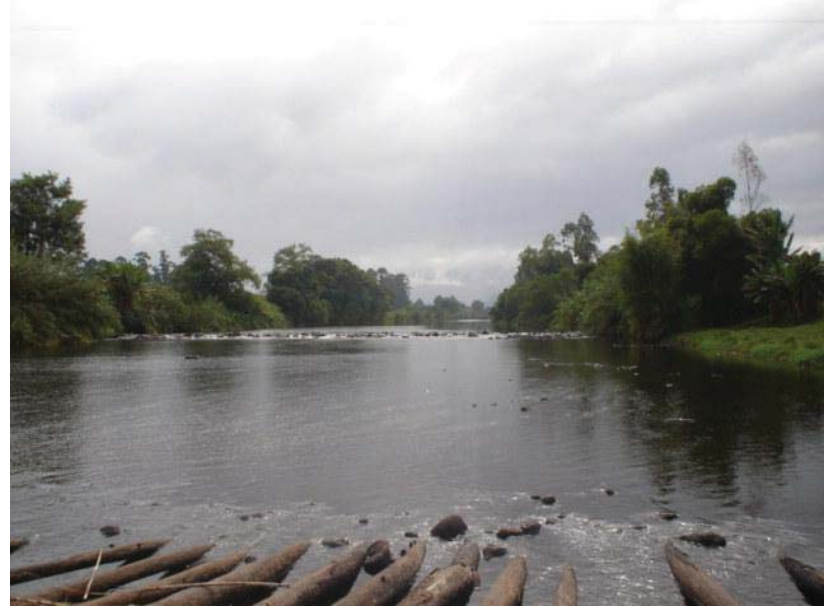

Figura 15 - Rio Amola Faca na localidade Rodeio d'Areia. Observar a presença de represas de madeira para acumular água para a rizicultura. O leito é muito raso, sem desnível em relação à planície.

Foto: Yasmine Cunha, abr./2006. solapada pela erosão das margens. 


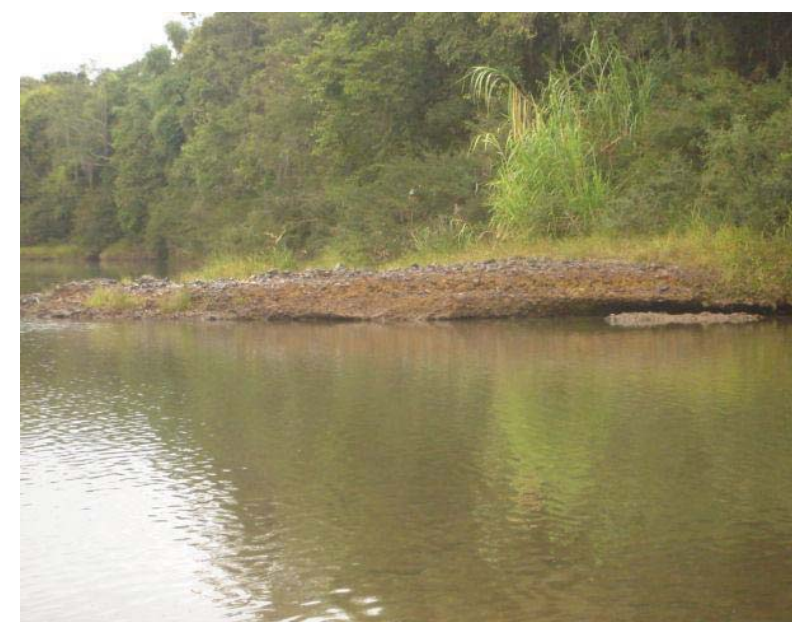

Figura 16 - Leito do rio Amola Faca, próximo da entrada para localidade de Santana. A erosão na margem do canal expõe depósito de clastos consolidados. Isto pode indicar relativa estabilidade de soterramento deste material para que ele tenha se consolidado, contudo agora, a sua exposição indica reativação dos processos de erosão pela migração do canal sobre estes depósitos.

Foto: Yasmine Cunha, abr. 2006.

No baixo curso do rio Amola Faca, antes dele ser denominado rio Itoupava e próximo da sua confluência com o rio das Pedras, existe um sítio de extração de seixos neste ponto, o rio possui canal largo e profundo, mas a sua morfologia foi modificada pela atividade de extração, pois para facilitar esta atividade são concentrados todos os clastos apenas de um lado do leito (Figura 17), o que muda a dinâmica do fluxo. A erosão que ocorria no lado oposto daquele onde estava o depósito de clastos, agora ocorre mais a jusante, na margem oposta de onde foi concentrado o depósito para extração (Figura 18). A erosão da margem derruba a vegetação de porte arbóreo. Outro problema causado pela extração de clastos na área é a presença de óleo das máquinas na água do rio (Figura 19).

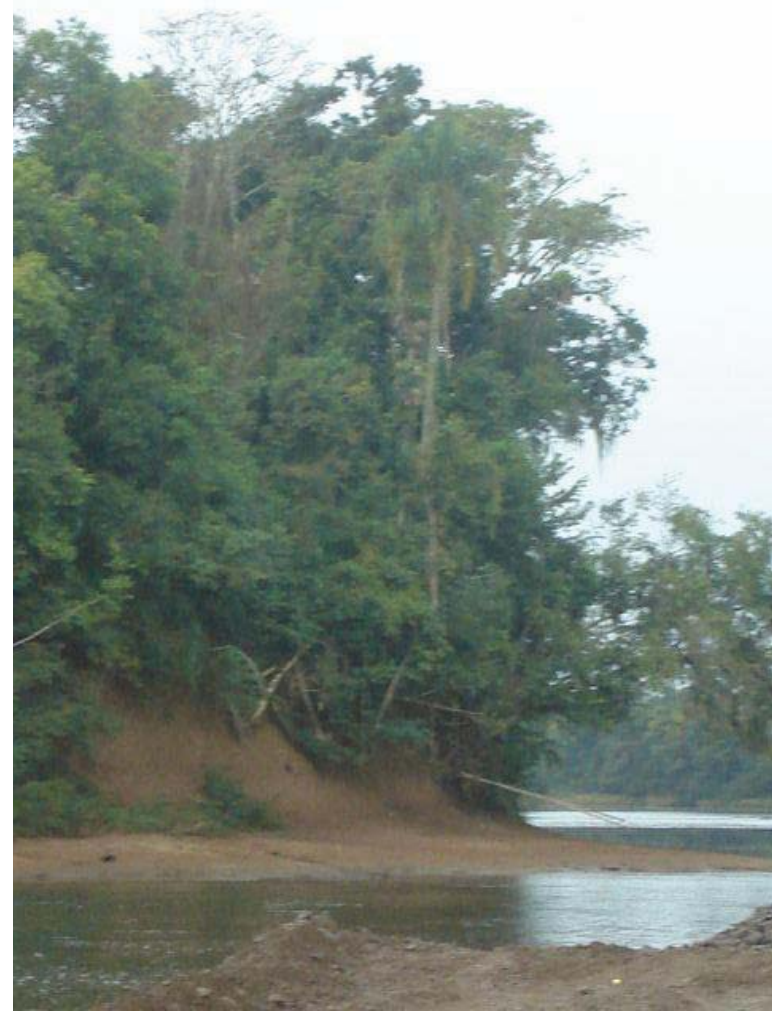

Figura 18 - Rio Amola Faca próximo da confluência com o rio da Pedra. Visão para jusante. Observar erosão da margem e queda de árvores a poucos metros a jusante do sítio de extração de clastos. descrito na Figura 21.

Foto: Yasmine Cunha, abr./2006.

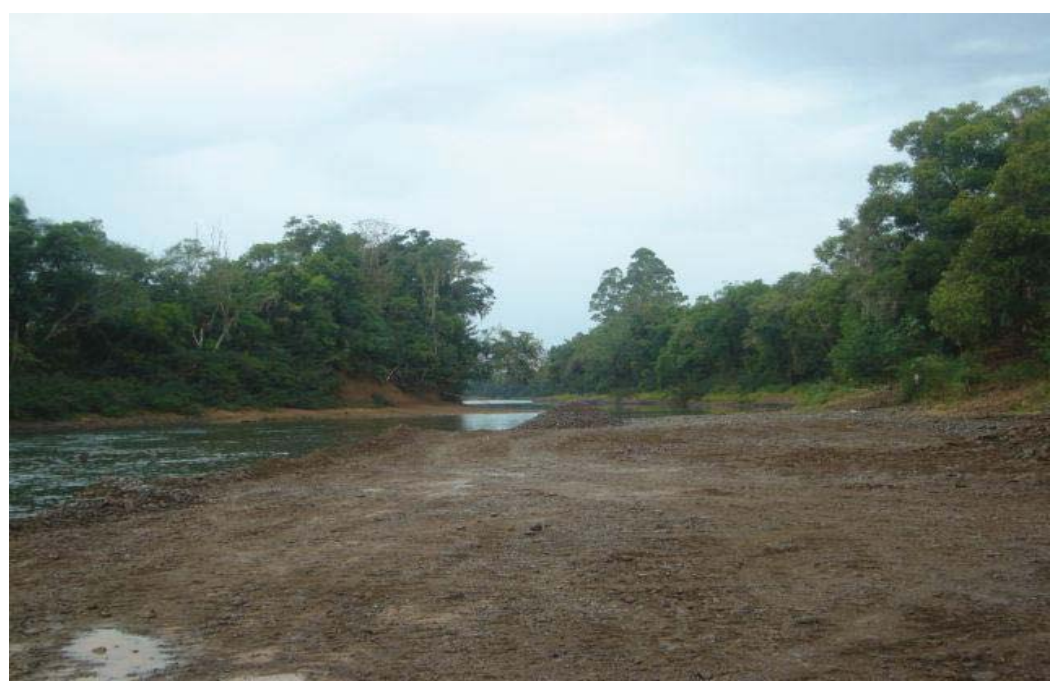

Figura 17 - Baixo vale do Rio Amola Faca próximo da confluência com o rio da Pedra. Sítio de extração de clastos. Observar o acúmulo de sedimentos em um dos lados do canal para facilitar a extração. Foto: Yasmine Cunha, abr. 2006. 

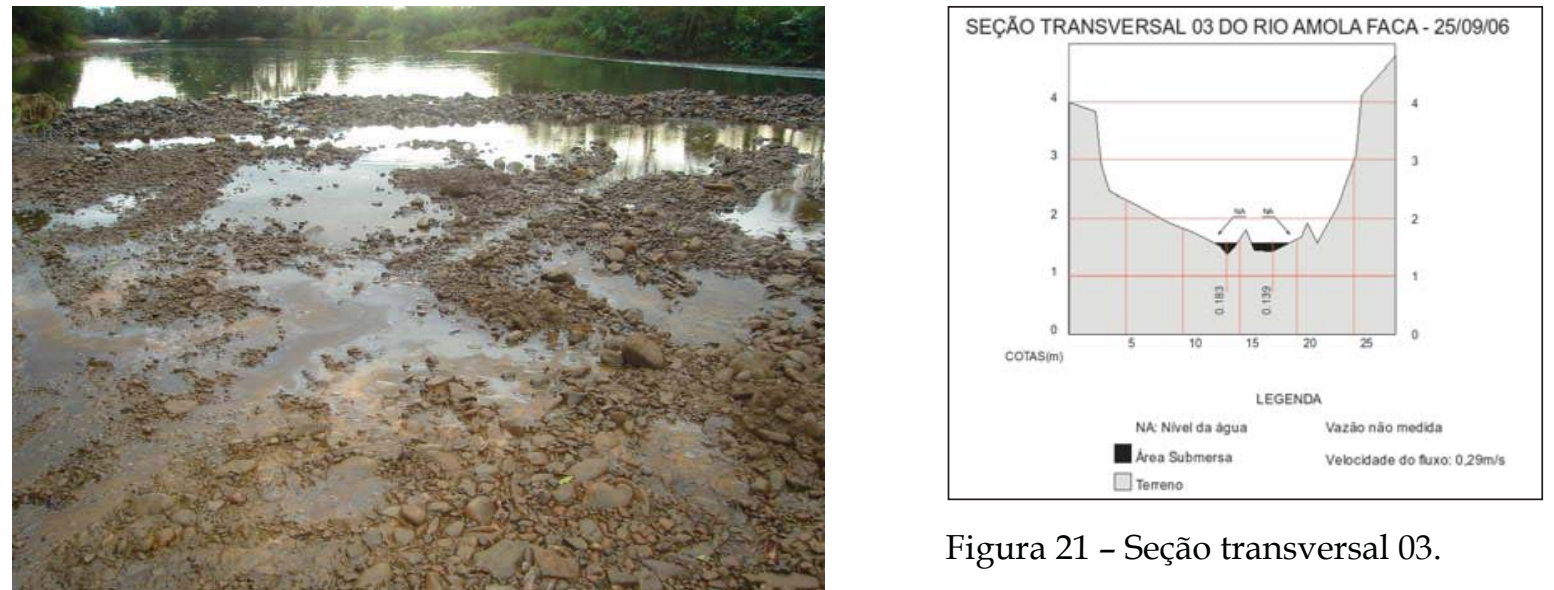

Figura 21 - Seção transversal 03.

Figura 19 - Sítio de extração de clastos no rio

Amola Faca próximo da confluência com o rio da Pedra. Detalhe da Figura 20. Observar o traçado de pneus e as manchas de óleo das máquinas que retiram os sedimentos do canal, contaminando a água e ${ }^{20200}$ modificando a morfologia do canal.

Foto: Yasmine Cunha, abr./2006.

Na figura 20, é possível visualizar alguns dos pontos descritos em que há erosão de margens e migração lateral do canal, além da extração de seixos e dos pontos de medição de seções transversais ao longo do médio vale do rio Amola Faca. Observar que nos locais onde há extração de seixos, há também focos de erosão de margens. Estas erosões ocorrem em margens que inclusive possuem mata ciliar.

As seções transversais medidas (Figuras $21,22,23$ e 24) mos-

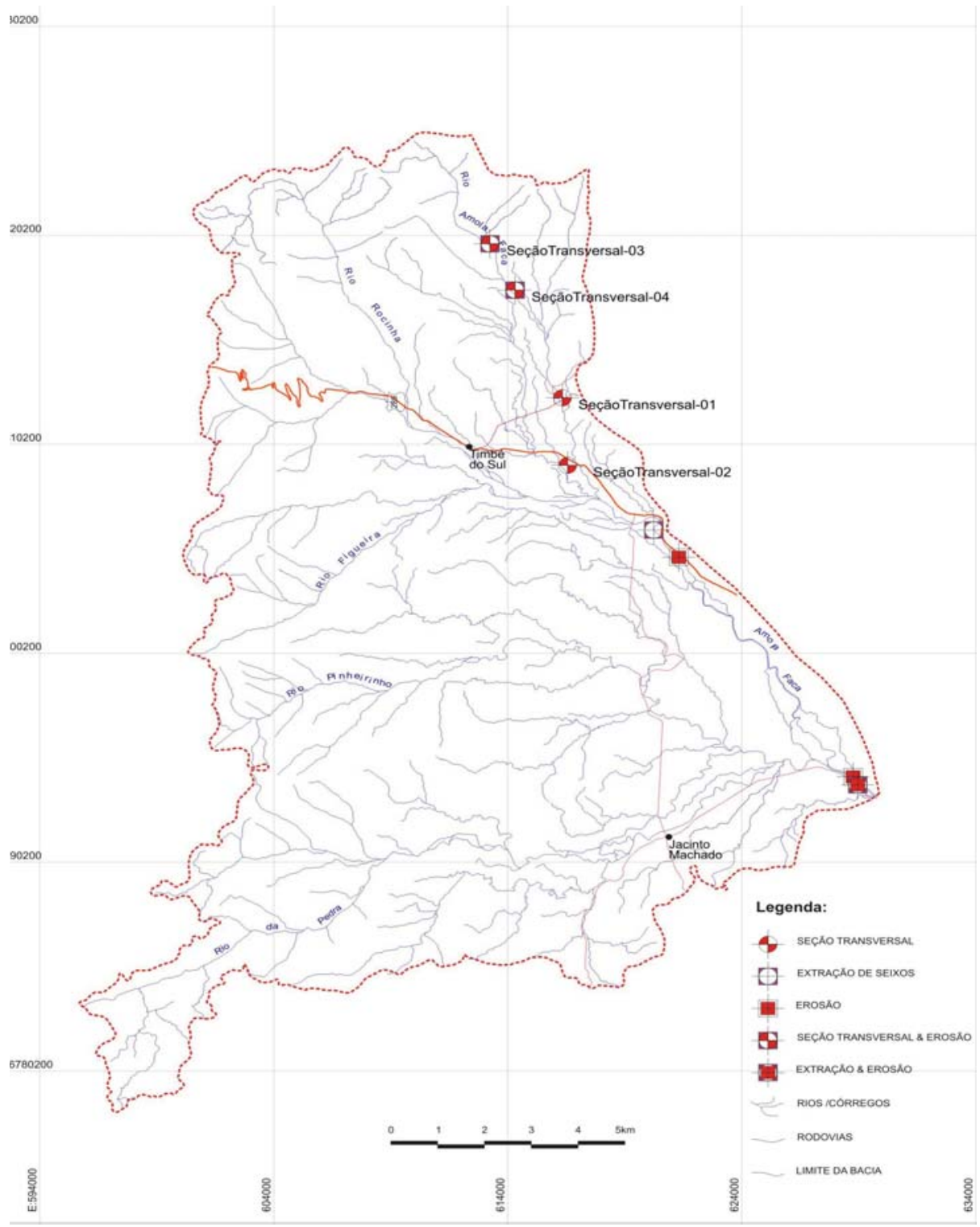

Figura 20 - Mapa de Localização dos pontos onde foram efetuadas as medidas das seções transversais e identificados os locais com erosão e com extração de seixos no canal do rio Amola Faca. 
EDNA Lindaura LUIZ

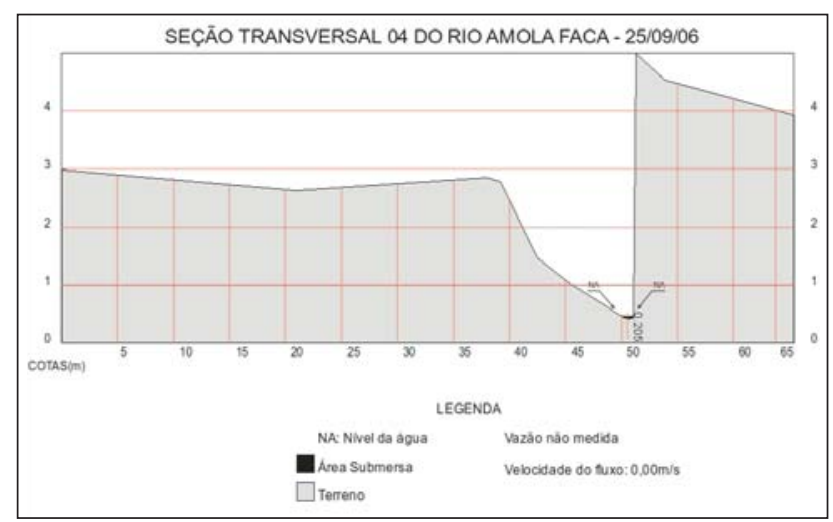

Figura 22 - Seção transversal 04.

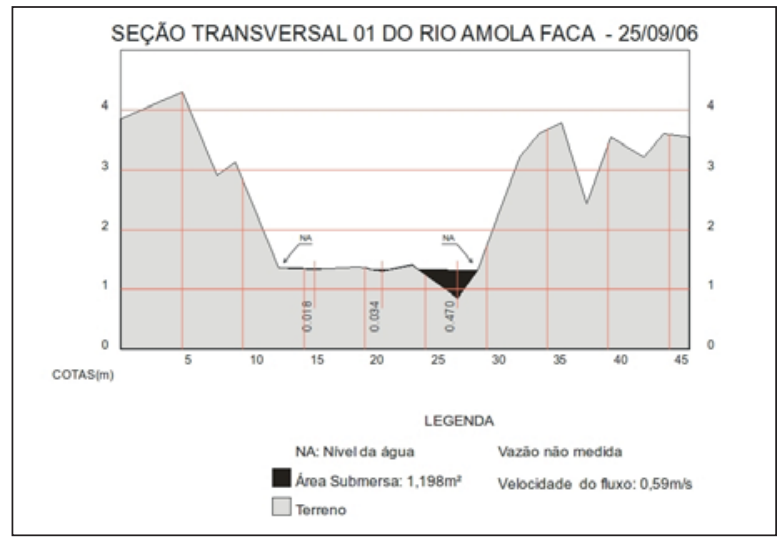

Figura 23 - Seção transversal 01.

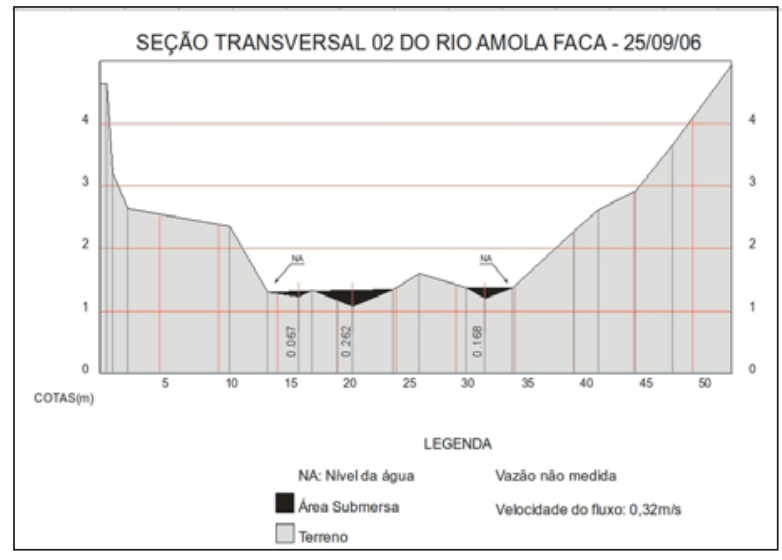

Figura 24 - Seção transversal 02.

tram uma morfologia de canal variável ao longo do percurso do rio e que o leito é mais encaixado em direção à montante, nas seções 03 e 04 .

\section{CONSIDERAÇÕES FINAIS}

Foi possível detectar que a bacia do rio Amola Faca não segue inteiramente os índices encontrados na literatura para a morfometria (relação de bifurcação e relação entre os comprimentos médios), provavelmente por causa da sua configuração fisiográfica de uma bacia com dois compartimentos de relevo bem distintos e com contato abrupto: escarpas da Serra Geral e planície costeira e a ocorrência de vazões excepcionais em função de chuvas orográficas nas encostas da Serra Geral que geram grande quantidade de carga sedimentar nos leitos dos rios. Essa carga se deposita assim que os declives diminuem na planície, provocando uma divisão dos fluxos pela barreira que estes depósitos se configuram.

Como o valor do índice de forma bacia do rio Amola Faca foi praticamente a metade da unidade $(0,56)$, diria-se que esta bacia não é propensa a cheias. Entretanto, ela é propensa a trombas d'água e enxurradas rápidas e perigosas por causa dos grandes desníveis e declividade da Serra Geral onde estão as nascentes e altos vales do rio principal e da maioria dos tributários, além de inundações na planície por causa das suas baixas altitudes, pequenos gradientes de escoamento e deposição de grandes quantidades de sedimentos que chegam das partes mais altas da bacia (encostas da Serra Geral).

Os índices morfométricos atestam que a rede de drenagem da bacia do rio Amola Faca ainda é influenciada pelas características geológicas dos terrenos, e pelo relevo com grandes contrastes altimétricos e fortes gradientes, além da grande quantidade de depósitos sedimentares na planície costeira.

A observação da dinâmica hidrológica e da configuração do canal do Rio Amola Faca em campo mostrou que na transição entre os compartimentos de sopé da serra 
geral e da planície costeira, existem muitos depósitos de clastos no leito e evidências de migrações laterais a partir da observação de braços de leitos abandonados reconhecidos através de depósitos alongados de clastos com embricamento (evidência de fluxos). Muitos trechos do leito apresentam desníveis em relação à planície e permitem indicar que houve encaixamento do canal em antigos depósitos ou por causa do seu entulhamento em momentos de vazões extremas durante precipitações excepcionais ou por mudanças no nível de base local ou geral por variações do nível do mar ou por alterações humanas no uso da terra solo e/ ou do canal.

Em alguns pontos, foi observada a extração de clastos de depósitos do leito do rio Amola Faca, com modificações na configuração do canal e evidências de erosão nas margens.

Também foi observado em campo que existem bombas para retirada de água do rio para o uso na agricultura e silvicultura. Também praticamente não existe mata ciliar na planície e, muito menos, recobrindo os terrenos da bacia neste compartimento de relevo. As terras dessa região são intensamente utilizadas para agricultura, especialmente, a cultura do arroz.

Em momentos de vazões extremas, foi constatado, por meio de evidências em campo e de entrevistas, que o fluxo do rio é capaz de erodir as margens e arrancar árvores do local, provocando a migração do leito ao longo da planície ou abandonando trechos inteiros de leitos ou se dividindo em vários 'braços' de leitos.

A medida de vazão não foi realizada porque grande parte do fluxo do rio corria abaixo dos significativos depósitos de clastos que recobrem o leito e não se poderia saber até que profundidade nestes depósitos havia água fluindo.

A existência de pequenas vazões no rio em seu médio vale durante muitos meses do ano e a existência de fluxo correndo embaixo de depósito de clastos no leito fazem pensar na viabilidade de um projeto que prevê a transposição das águas deste rio para a barragem do rio do Salto e para o rio Manoel Alves situados em outras bacias hidrográficas mais à nordeste, pois já não existe fluxo suficiente em boa parte do ano para os próprios usuários da bacia. Estas obras serão construídas pelo governo de Santa Catarina por intermédio da Companhia Catarinense de águas e Esgotos (CASAN).

Sabe-se que o projeto fala em usar a água do rio Amola Faca nos momentos de maior vazão, mas estas podem ser muito perigosas conforme evidências encontradas nas visitas a campo. A construção de uma barragem para a realização da transposição pode se constituir em uma estrutura que representa risco para as comunidades a jusante, uma vez que pode acumular água e sedimentos em momentos de vazões excepcionais e romper com a força do fluxo, permitindo a criação de uma tromba d'água para jusante da área de barramento e provocando grande desastre natural.

\section{REFERÊNCIAS}

BROOKES, A. River Channelization: traditional engineering methods, physical consequences and alternative pratices. Progress in Physical Geography, v. 9, n. 1, p. 44-73, 1985.

CHRISTOFOLETTI, A. Geomorfologia. São Paulo: Edgard Blücher, 1980.

Geomorfologia fluvial. São Paulo: Edgard Blücher, 1981.

CUNHA, S. B. Geomorfologia fluvial. In: GUERRA, A. J. T.; CUNHA, S. B. (Orgs.). Geomorfologia: uma atualização de bases e conceitos. Rio de Janeiro: Bertrand Brasil, 1994.

CUNHA, S. B. Impactos das obras de engenharia sobre o ambiente biofísico da Bacia do Rio São João - Rio de Janeiro - Brasil. Rio de Janeiro: Edição do Autor, 1995. 
DANTAS, M.; GOULART, D. R.; JACQUES, P. D. et al. Geomorfologia aplicada a gestão integrada de bacias de drenagem: Bacia do rio Araranguá (SC), zona carbonífera sul catarinense. In: Estudos hidrológicos e hidrogeológicos da bacia hidrográfica do rio Araranguá (SC) (Mapas e Relatório). CPRM-DEHID-SURIG-PA, 2005.

HORTON, R. E. Erosional development of streams and their drainagens basins: hydrophisical approach to quantitative morph. Geol. Soc. Am. Bull, n. 56, 275-370, 1945.

PELLERIN, J.; DUARTE, G. M.; SCHEIBE, L. F.; MENDONÇA, M.; BUSS, M. D.; MONTEIRO, M. A. Timbé do Sul - Jacinto Machado: avaliação preliminar da extensão da catástrofe de 23 - 24 dez. 1995. Revista Geosul, Florianópolis, v. 12, n. 23, p. 71-83, 1997.

PELLERIN, J.; GAMA, A. M. C.; NASCIMENTO, E. E. D. J. et. al. Zoneamento e efeitos morfodinâmicos da enxurrada do dia 23/12/1995 nas bacias dos rios Figueira e Pinheirinho - SC. Revista Sociedade e Natureza, Uberlândia, v. 8, n. 15, p. 196-200, 1996.

PELLERIN, J.; OLIVEIRA, M. A. T; SCHEIBE, L. F. et al. Les crues et laves torrentielles catastrophiques du 23 décembre 1995 dans l'État de Santa Catarina (Brésil subtropical). Geomorphologie: Relief, Processus, Environnement, n. 1, p. 51-60, 2002.

PONTELLI, M. E. Pedo-estratigrafia em depósitos de leques aluviais na bacia hidrográfica do rio Itoupava, sul de Santa Catarina. Tese (Doutorado em Geografia) - Universidade Federal de Santa Catarina, Florianópolis, 2005.

PONTELLI, M. E. Cartografia das alterações em depósitos de leques aluviais como base para uma estratigrafia relativa, bacias dos rios Amola Faca e Rocinha, Timbé do Sul - SC. Dissertação (Mestrado em Geografia) - Universidade Federal de Santa Catarina, Florianópolis, 1998.

RICE, R. J. Fundamentos de geomorfología. Madrid: Paraninfo, 1983.

STRAHLER, A. N. Geografia física. 6. ed. Barcelona: Omega, 1982.

SUGUIO, K.; BIGARELLA, J. J. Ambientes fluviais. Florianópolis: UFSC, 1990.

WIZGA, B. River response to channel regulation: case study of the Raba River, Carpathians, Poland. Earth Surface Processes and Landforms. v. 18, p. 541-556, 1993.
Recebido em 28/09/2009

Aceito em 01/11/2009 